УДК 378.147:37.011.3

(C) Ткачов А. С., Ткачова Н. О., Щебликіна Т. А. 2020

https://orcid.org/0000-0002-4488-1466

https://orcid.org/0000-0002-1892-9200

https://orcid.org/0000-0002-7135-3757

https://doi.org/10.34142/23128046.2020.49.10

A. C. Ткачов

Н. О. Ткачова

T. А. Щебликіна

\title{
АВТОРСЬКА МОДЕЛЬ ОРГАНІЗАЦІЇ САМОСТІЙНОЇ НАВЧАЛЬНОЇ ДІЯЛЬНОСТІ ЗДОБУВАЧІВ ВИЩОЇ ПЕДАГОГІЧНОЇ ОСВІТИ НА ОСНОВІ ВИКОРИСТАННЯ ЦИФРОВИХ ТЕХНОЛОГІЙ
}

У статті визначено, щзо протягом останніх місяиів в Украӥні та світі загалом виникли принципово нові освітні реалії, які значно підвищують значення самостійної навчальної діяльності в системі професійної підготовки майбутніх учителів на основі використання цифрових технологій. Мета статті - представлення авторської моделі організачії самостійної навчальної діяльності майбутніх учителів на основі використання цииррових технологій та результатів експериментальної перевірки ї ефективності. Зазначена модель включає такі блоки: концептуально-цільовий блок (мета, завдання), структурно-змістовий (змістове наповнення структурних складників системи цииррових технологій); технологічно-процесуальний (використання цииррових технологій на всіх етапах організації самостійної навчальної діяльності студентів); критеріально-результативний (критерії ефективності та рівні організаиіі самостійної навчальної діяльності студентів на основі використання цифрових технологій; діагностичний інструментарій; очікуваний результат). На аналітико-підготовчому етапі організаиіі самостійної навчальної діяльності студентів на основі використання цифрових технологій розроблялося відповідне інформаційно-методичне забезпечення, що включало навчальну програму з чітким відображенням змісту та обсягу иієї діяльності з кожної теми, опорний контекст лекцій в електронній формі, список рекомендованих джерел та інші матеріали. На мотиваційно-організаційному етапі організації самостійної навчальної діяльності проводилося ознайомлення студентів з указаним забезпеченням, відбувались індивідуальні та групові консультаиї, розроблявся індивідуальний освітній маршрут для кожного студента. На змістово-діяльнісному етапі майбутні педагоги безпосередньо реалізовували самостійну навчальну діяльність на основі використання иифрових технологій. На рефлексивнокоригувальному етапі забезпечувалися самоконтроль $і$ самооцінка засвоєних студентами необхідни для самостійного навчання знань, умінь, 
компетентностей. Результати проведеного експерименту довели, щзо реалізація розробленої моделі дійсно забезпечує підвищення ефективності організачії самостійної навчальної діяльності студентів.

Ключові слова: самостійна навчальна діяльність, майбутній учитель, цифрова технологія, авторська модель, вища педагогічна освіта.

\section{Tkachov A., Tkachova N., Shcheblykina T. Author's model of self-directed} learning activities for undergraduate students of higher pedagogical education based on the application of digital technologies. The article states that there have arisen principally new educational realities in Ukraine and in the world as well during recent months, what is significantly raising importance of selflearning based on digital technology application amongst the students of pedagogical specialties. The purpose of the article is to introduce an author's model of selfdirected learning activities for undergraduate students of higher pedagogical education based on the application of digital technologies as well as to provide the experimental verification results of its effectiveness. The model contains such blocks as a conceptual-purposeful block (a purpose, objectives), a structural-content block (content of structural components of digital technologies system), a technologicalprocedural block (digital technologies application at all the stages of students' selflearning); a criteria-result block (the criteria of effectiveness and levels students' self-learning management by means of digital technologies, diagnostic tools, expected outputs). At the analytical preparation stage of students' self-learning management by means of digital technologies it has been developed specific information and methodological provision, including the curriculum with a clear reflection of the content and scope of activity on each topic, reference lecture notes in electronic version, a list of recommended sources and other materials. At the motivational and organizational stage of the students' self-learning the students got familiar with the specified provision, personal and group tutorials were conducted, a personal educational path was designed for each student. At the content-activity stage future teachers directly carried out self-learning by means of digital technologies. At the reflexive-corrective stage, self-control and self-assessment of students' knowledge and skills necessary for self-learning were ensured. The outputs of the experiment have proved that the implementation of the developed system ensures the optimal management of students' self-learning activities.

Keywords: independent educational activity, future teacher, digital technology, author's model, higher pedagogical education.

Вступ. Протягом останніх півроку в Україні та інших країнах світу виникли принципово нові освітні реалії, які вимагають значного зростання ролі самостійної діяльності в системі професійної підготовки майбутніх фахівців та активного використання в процесі іiі здійснення цифрових технологій. Указані зміни в організації цієї підготовки зумовлюють необхідність підвищення відповідальності майбутніх фахівців за оволодіння професійною 
компетентністю, успішну реалізацію ними на практиці задекларованої ідеї про необхідність розробки кожним із них власної індивідуальної освітньої траєкторії.

Зазначені вимоги знайшли відображення в провідних нормативних документах у галузі освіти (закони України «Про освіту», «Про вищу освіту», «Про Національну програму інформатизації» тощо), в яких наголошується, що оволодіння кожним суб'єктом навчання вміннями й навичками працювати самостійно є необхідною передумовою для успішного здійснення неперервного професійного самовдосконалення протягом усього життя. При цьому активне використання комп'ютерних засобів дає змогу суттєво підвищити ефективність самостійної навчальної діяльності студентів, а також іiі управління на основі використання сучасних інформаційних технологій в умовах динамічно змінного інформаційного суспільства.

3 огляду на викладене вище актуальною проблемою сьогодення $\epsilon$ використання цифрових технологій в організації самостійної навчальної діяльності майбутніх фахівців. Причому найбільш гостро ця проблема постає перед закладами вищої педагогічної освіти, адже саме на випускників зазначених закладів покладається складна й почесна місія розбудови в Україні Нової української школи.

Як визначено на основі вивчення досліджень в обраному й суміжних наукових напрямах, провідні вітчизняні та зарубіжні вчені у своїх працях висвітлили різні актуальні питання, пов'язані з обраною тематикою, зокрема: сучасні вимоги до організації самостійної навчальної діяльності студентів, можливості підвищення іiі ефективності засобами комп'ютерних технологій (Л. Баумгартнерц, Н. Бойко, Р. Каффарелла, Н. Лонг, О. Малихін, С. Мерріам та ін.); умови використання інформаційних технологій у професійній підготовці майбутніх фахівців різних спеціальностей, теоретичні та практичні аспекти формування інформаційно-освітнього середовища i, зокрема, цифрового освітнього середовища закладу освіти (Н. Бахмат, М. Долінс, Л. Карташова, Т. Коваль， С. Литвинова， Н. Майєр， О. Пітерс， І. Пліш та ін.); авторські методики професійного навчання майбутніх учителів на основі застосування інформаційно-комунікативних технологій і забезпечення готовності шкільних педагогів до використання цих технологій у професійній діяльності (В. Андрієвська, О. Муковіз, О. Цись та ін.). Зазначимо, що науковці зробили вагомий внесок у розкриття різних аспектів порушеної проблеми. Водночас зауважимо, що іiі недостатнє теоретичне та практичне дослідження, активні зміни в організації освітнього процесу у вищій школі та інтенсивний розвиток цифрових технологій зумовлюють доцільність продовження наукового пошуку у визначеному напрямі.

Мета та завдання. Метою статmі є представлення авторської моделі організації самостійної навчальної діяльності майбутніх учителів на основі використання цифрових технологій. Визначену мету конкретизовано в таких завданнях: розкрити суть авторської моделі організації зазначеної діяльності на 
основі використання цифрових технологій; навести, узагальнити та проаналізувати результати впровадження цієї моделі в освітній процес у вищій педагогічній школі.

Методи дослідження. Для розв’язання поставлених вище завдань використовувався комплекс таких методів дослідження, як: теоретичні аналіз наукових джерел, порівняння й систематизація поглядів учених щодо застосування цифрових технологій в організації самостійної навчальної діяльності майбутніх учителів; узагальнення теоретичних положень задля визначення наукового тезаурусу дослідження; емпіричні - спостереження, анкетування, бесіди, тестування, вивчення продуктів діяльності студентів.

Результати. Представлення результатів проведеного наукового пошуку передбачає авторське розуміння поняття «самостійна навчальна діяльність». Як установлено в дослідженні, це поняття вітчизняні вчені трактують як: діяльність суб'єктів навчання, що реалізується під час здійснення цього процесу за умови безпосереднього невтручання викладача, відповідає вимогам навчальних планів і програм закладу вищої освіти та спрямовується на пізнання обраного об'єкта, засвоєння необхідного досвіду (Malykhin, 2010); складне багатомірне педагогічне явище, що включає системну цілісність структурних $\mathrm{i}$ функціональних компонентів, підпорядковану визначеним цілям в умовах іiі опосередкованого управління й самоуправління (Воyko, 2008); різноманітні види діяльності, що виконується суб'єктом навчання на аудиторних заняттях або в позааудиторний час за завданням та під керівництвом педагога, однак без його безпосередньої участі (Goncharenko, 1997).

Зарубіжні вчені - Л. Баумгартнерц, Р. Каффарелла, Н. Лонг, С. Мерріам, М. Ноулс - під самостійною навчальною діяльністю розуміють такий вид діяльності, під час реалізації якої студенти проявляють ініціативу у визначенні власних освітніх потреб i на підставі цього формулюють мету майбутньої діяльності, знаходять способи їі досягнення та наявні для цього матеріальні й особистісні ресурси, а також здійснюють оцінювання отриманих поточних i кінцевих результатів (Merriam, Caffarella, Baumgartner, 2007; Long, 2000; Knowles, 1995). Н. Боер, Дж. Холл, П. Усінгер наголошують на тому, що під час здійснення самостійної діяльності відповідальність за іiі перебіг та результати несе той, хто ii реалізує, водночас викладачі мають забезпечувати дієвий педагогічний супровід цієї діяльності, причому обсяг і зміст такого супроводу має бути зумовлений як специфікою діяльності, так i навчальними досягненнями та індивідуальними інтересами іiі суб'єктів (Boyer, Usinger, 2015; Hall, 2020).

На основі врахування наведених вище позицій науковців зроблено висновок про те, що самостійна навчальна діяльність студентів - це організаційно спланована й методично скоординована пізнавальна діяльність студентів, яка не передбачає безпосереднього втручання викладача, відповідає вимогам і змісту освітньо-професійних програм та спрямована на засвоєння 
майбутніми фахівцями визначених компетенцій, стимулювання професійноособистісного становлення кожного студента.

Зазначимо, що в науковій літературі виокремлюють різні види самостійної навчальної діяльності студентів на основі тих чи інших ознак, а саме: за джерелом управління (контролю) - проводиться під контролем педагога чи за допомогою самоконтролю студентів; за характером здійснення - відбувається в заданому ззовні режимі або в режимі, обраному суб'єктом навчання; за характером спонукача - виконується за ініціативою педагога або за власною ініціативою студента; за присутністю педагога як джерела управління реалізується в присутності викладача або без нього; за фіксуванням місця проведення - відбувається у визначеному місці (наприклад, у конкретній аудиторії) чи в попередньо невизначеному місці; за рівнем обов'язковості може бути обов'язковою, тобто ії зміст передбачений навчальними планами i робочими програмами, і необов'язковою, коли проводиться студентом за власним бажанням у позааудиторний час (Zymnyaya, 1999; Rybak, Baumwald, Pisarik, 2020; Tkachova, Kabanska, 2018).

Як засвідчує аналіз наукової літератури, ефективним засобом організації самостійної навчальної діяльності студентів $\epsilon$ сучасні цифрові технології. За висновками О. Овчарук, ці технології створюють необхідні передумови не тільки для застосування їх у різних видах навчальної діяльності, але й для встановлення зворотного зв'язку щодо використання зазначених технологій, застосування й удосконалення суб'єктами навчання власної цифрової компетентності. Причому використаний інструментарій має бути адаптованим до кожної аудиторії, відрізнятися різноманітністю та слугували ефективним засобом установлення зворотного зв'язку, даючи змогу всім учасникам краще зрозуміти власні сильні та слабкі сторони й визначити конкретні шляхи досягнення успіху (Ovcharuk, 2020: 6).

Варто також зазначити, що з 2018 р. в Україні розпочалося реформування шкільної освіти, спрямоване на розбудову Нової української школи. Успішно виконати сьогодні поставлені перед школою завдання зможуть тільки ті вчителі, які на належному рівні володіють цифровою компетентністю. Спираючись на опис цифрової компетентності у вказаній вище Рамці та враховуючи сучасні доробки в царині стандартизації цифрової компетентності, О. Овчарук серед основних показників, яким має відповідати сучасний шкільний педагог, визначила такі: керування інформацією (здатність до пошуку необхідної інформації, ï аналіз і використання в професійній діяльності); співробітництво (готовність брати участь у роботі онлайн-спільнот та взаємодії з іншими користувачами в мережі Інтернет); комунікація (уміти спілкуватися за допомогою онлайн-інструментів із дотриманням вимог конфіденційності, безпеки та мережевого етикету); створення контенту і знань (готовність до прояву творчості, уміння створювати нові знання й контент засобами ІКТ); етика і відповідальність (належна етична поведінка в мережі Інтернет); оцінювання та розв'язання проблем (здатність доцільного добору IКТ для 
оцінювання й самооцінювання знань, умінь і навичок у межах викладання профільних предметів для вирішення наявних проблем, опрацювання результатів оцінювання за допомогою ІКТ і надання відповідних консультацій); технічне оперування (готовність ефективно, безпечно й доцільно використовувати IКТ у професійній і навчальній діяльності) (Ovcharuk, 2018: $52-53)$.

Як визначено в дослідженні, забезпеченню підготовки майбутніх учителів згідно з вимогами часу сприяе залучення їх до самостійної навчальної діяльності, організація якої відбувається на основі застосування різних цифрових технологій. У світлі цього виникає необхідність у розробленні й реалізації науково обгрунтованої моделі організації самостійної навчальної діяльності здобувачів вищої педагогічної освіти на основі використання цих технологій.

На підставі опрацювання наукової літератури та врахування власних практичних доробок було розроблено модель організації самостійної навчальної діяльності майбутніх педагогів на основі використання цифрових технологій, що включає концептуально-цільовий, структурно-змістовий, технологічно-процесуальний та критеріально-результативний блоки.

Так, перший із них містить мету та завдання моделі. Зокрема, метою іiі реалізації $є$ підвищення ефективності організації самостійної навчальної діяльності майбутніх учителів шляхом використання цифрових технологій. Сформульовану мету конкретизовано в низці таких завдань: за допомогою використання цифрових технологій активізувати розвиток у студентів мотивів щодо самостійного навчання, покращити результати їхньої самостійної навчальної діяльності, забезпечити формування в них цифрової компетентності.

У структурно-змістовому блоці моделі представлено структурні складники системи цифрових технологій. Так, іiі організаційно-управлінський складник забезпечує процес управління самостійною навчальною діяльністю її суб'єктів. Провідне місце в цьому процесі займає платформа Moodle (Modular ObjectOriented Dynamic Learning Environment), яка має значні можливості для здійснення оперативної взаємодії між викладачами та здобувачами вищої педагогічної освіти, надання їм оперативної педагогічної підтримки.

Зокрема, управління зазначеною діяльністю майбутніх учителів здійснюється на основі широкого використання таких представлених у системі Moodle засобів комунікації, як: електронна пошта, обмін вкладеними файлами, форум, чат, ведення блогів тощо. У процесі управління самостійною навчальною діяльністю студентів передбачається також використання й інших платформ, насамперед, Zoom та Meet.

Змістово-ресурсний складник системи цифрових технологій відбиває сукупність цифрових ресурсів, які передбачається використовувати майбутніми учителями в процесі здійснення самостійної навчальної діяльності. Цей складник містить різні цифрові ресурси (навчальні, довідкові, методичні тощо), зокрема такі: розроблені викладачами інформаційно-навчальні матеріали, 
наукові й довідкові джерела, фотографії, відеофрагменти, динамічні чи статичні моделі, каталоги, кейсові і проєктні завдання тощо. Чільне місце серед них займають ресурси, представлені викладачами в системі Moodle, зокрема розроблені ними курси з відповідними гіперпосиланнями та завданнями для самостійної навчальної діяльності студентів та методичні рекомендації щодо здійснення цієї діяльності.

Оцінно-діагностичний складник указаної системи використовується для здійснення поточної діагностики результатів самостійної навчальної діяльності іiі суб'єктів, що дозволяє вносити своєчасні необхідні зміни в організацію цієї діяльності. Серед цифрових технологій, які доцільно використовувати для цього, можна назвати такі: електронне опитування, тестування, цифрові системи контролю знань здобувачів, аналіз їхніх відповідей на запитання вікторини, результатів виконання кейсових завдань i проєктів, цифрове портфоліо навчальних досягнень тощо.

Як визначено в технологічно-процесуальному блоці моделі алгоритму, використання цифрових технологій відбувається на всіх етапах організації самостійної навчальної діяльності здобувачів. Так, на їі аналітико-підготовчому етапі аналізуються наявні можливості щодо використання різних цифрових технологій в організації самостійної навчальної діяльності майбутніх учителів, відбирається відповідний цифровий інструментарій.

Організаційно-мотиваційний етап організації самостійної навчальної діяльності здобувачів спрямований на їх ознайомлення 3 указаним інструментарієм, проведення на основі використання цифрових технологій індивідуальних, групових, установчих консультацій, а також розроблення індивідуального освітнього маршруту кожного студента, що дає змогу конкретизувати режим і зміст виконання самостійної роботи на основі врахування персональних інтересів і потреб особистості.

Змістово-діяльнісний етап пов'язаний із безпосередньою реалізацією майбутніми педагогами самостійної навчальної діяльності на основі використання цифрових технологій. На цьому етапі передбачається застосування різних цифрових ресурсів, зокрема таких, як: підготовлених викладачами навчальних і довідкових ресурсів, розміщених на базі Moodle; ресурсів цифрового репозиторію закладу освіти, де викладені конспекти лекцій, методичні вказівки, навчальні посібники й підручники, автореферати, дисертації, магістерські роботи, наукові статті, журнали тощо; наукових ресурсів, представлених у мережі Інтернет: монографій, дисертацій, наукових журналів, матеріалів науково-практичних конференцій, вебінарів тощо; інформаційно-довідкових ресурсів (довідники, словники, енциклопедії); різних навчальних ресурсів, що об'єднані за цільовим призначенням, формою технічного виконання та видами інтерфейсу; підручників i посібників, тренажерів, дидактичних ігор тощо.

На рефлексивно-коригувальному етапі організації самостійної навчальної діяльності студентів на основі використання цифрових технологій здійснюється 
оцінювання ii результатів викладачами та самими суб'єктами навчання. Для цього використовуються різні цифрові технології.

У критеріально-результативному блоці розробленої моделі представлено механізм визначення ефективності організації самостійної навчальної діяльності майбутніх учителів на основі використання цифрових технологій. Для цього визначено такі критерії й показники: мотиваційний (сформованість мотивів студентів щодо здійснення самостійної навчальної діяльності на основі застосування цифрових технологій), когнітивний (сформованість знань, потрібних для виконання цієї діяльності), процесуальний (сформованість умінь здійснювати самостійну навчальну діяльність на основі застосування цифрових технологій).

3 урахуванням цих критеріїв та показників у вказаному блоці виокремлено три рівні організації самостійної навчальної діяльності майбутніх учителів на основі використання цифрових технологій: низький (майбутні педагоги демонструють слабо розвинені мотиви щодо здійснення самостійної навчальної діяльності, засвоєні знання та вміння дають змогу здійснювати репродуктивну самостійну діяльність на основі застосування цифрових технологій); середній (студенти епізодично проявляють мотиви щодо здійснення самостійної навчальної діяльності, засвоєні знання та вміння дають змогу виконувати реконструктивну самостійну діяльність на основі застосування цифрових технологій), високий (майбутні учителі мають стійкі мотиви щодо здійснення самостійної діяльності, сформовані знання та вміння дають змогу здійснювати самостійну діяльність творчого характеру на основі використання цифрових технологій).

Для перевірки ефективності розробленої системи організації було організовано педагогічний експеримент, який проводився впродовж 2019-2020 pp. та до якого було залучено 169 студентів Харківського національного педагогічного університету імені Г.С.Сковороди та Харківського національного університету імені В.Н. Каразіна. Експеримент охоплював організацію самостійної навчальної діяльності майбутніх педагогів на основі використання цифрових технологій у процесі вивчення педагогічних дисциплін та іноземних мов.

Так, на першому етапі організації самостійної навчальної діяльності майбутніх учителів на основі використання цифрових технологій було розроблено відповідне інформаційно-методичне забезпечення, що включало конкретні цифрові матеріали: навчальну програму із чітким відображенням змісту та обсягу цієї діяльності 3 кожної теми; опорний контекст лекцій; методичні вказівки, в яких наведено цілі, графік та вимоги щодо виконання студентами різних видів самостійної роботи та очікувані іiі результати у вигляді засвоєння конкретних загальних та професійних компетенцій; алгоритм здійснення кожної конкретної роботи та форма представлення отриманих результатів, рекомендовані цифрові засоби для виконання поставлених завдань тощо); перелік питань для обговорення на семінарських заняттях, завдань, тем 
проєктів із зазначенням цифрових технологій, що рекомендовані до використання під час їх виконання; комплекти електронних контрольних завдань, тестів, що передбачають можливість здійснення електронної самоперевірки; вимоги до складання цифрових портфоліо та їх зразки тощо. Ці матеріали було представлено на базі Moodle.

На другому етапі організації самостійної навчальної діяльності майбутніх учителів проводилося ознайомлення їх із указаним інформаційно-методичним забезпеченням, проведення індивідуально-групових установчих консультацій для уточнення суті, змісту різних видів самостійної роботи, надання порад щодо використання під час іiі здійснення різних цифрових технологій, уточнення термінів і форм перевірки та контролю отриманих результатів, роз'яснення незрозумілих аспектів в організації самостійного навчання. На цьому етапі також проводився аналіз навчальних досягнень студентів і їхньої готовності до проведення самостійної роботи.

Важливим аспектом педагогічної взаємодії було також визначення індивідуального освітнього маршруту для кожного учасника процесу навчання. Цей маршрут визначався у вигляді індивідуального комплексу різнорівневих навчальних завдань та особистої програми дій, а також опису запланованої педагогічної підтримки майбутнього фахівця в його професійно-особистісному становленні. Зазначимо, що розроблення таких маршрутів сприяло розвитку мотивації здобувачів до виконання запланованої самостійної навчальної діяльності, а також створювало сприятливі передумови для їхньої професійноособистісної самореалізації.

На третьому етапі організації самостійної діяльності майбутніх учителів відбувалися самоорганізація та безпосередня реалізація ними різних форм самостійної навчальної діяльності репродуктивного (самостійна діяльність виконувалася за певним зразком на основі попередньо запропонованих цифрових технологій), реконструктивного (самостійна діяльність спрямована на внесення певних кількісних або якісних змін в об'єкт вивчення iз застосуванням різних цифрових технологій) та творчого (самостійна діяльність забезпечує пошук і реалізацію студентом власного нестандартного рішення запропонованого завдання на основі самостійного обрання певних цифрових технологій).

Варто також зауважити, що в процесі організації самостійної діяльності майбутніх учителів значна увага приділялася забезпеченню їхнього професійного становлення як майбутніх педагогів. Задля цього добиралися завдання, виконання яких сприяло збагаченню досвіду кожного 3 них використовувати цифрові технології в майбутній педагогічній діяльності. Здобувачі вищої педагогічної освіти в процесі самостійного навчання могли використовувати навчальні, довідкові й методичні матеріли, розміщені викладачами на платформі Moodle, цифрові освітні системи MOOC (масовий безкоштовний онлайн-курс) та $\mathrm{EdX}$ (безкоштовна інтернет-платформа масових 
відкритих інтерактивних курсів), електронні курси на вікі-порталах закладу освіти тощо.

У процесі проведення експерименту здобувачі самостійно виконували різного виду репродуктивні завдання, зокрема опрацьовували запропоновані викладачем на заняттях цифрові навчальні матеріали, вивчали нові дані про об'єкт вивчення за вказаним електронним джерелом інформації, виконували завдання за алгоритмом, знаходили відповіді на поставлені питання, відпрацьовували певні граматичні правила тощо. Це передбачало застосування різних цифрових технологій.

Зазначимо, що майбутні педагоги під час пошуку потрібної інформації часто зверталися до використання ресурсів мережі Інтернет, зокрема пошукових систем Google i Meta. У світлі цього під час надання педагогічної підтримки студентам викладачі приділяли значну увагу обговоренню 3 ними того, які джерела інформації варто вважати достовірними. Так, рекомендувалося використовувати такі з них: електронні підручники, цифрові навчальні курси, енциклопедії та інші види довідкових систем, відцифровані першоджерела (газети, журнали, документи, фотографії та інші фактологічні матеріали минулого), електронні журнали, газети, словники та онлайнперекладачі, наукові монографії, статті, дисертаційні праці та автореферати дисертацій тощо. Також здобувачам вищої педагогічної освіти радили вивчати нормативні документи, представлені на сайті Міністерства науки і освіти України (mon.gov.ua), матеріали офіційних сайтів різних закладів освіти, електронних ресурсів інформаційних порталів та електронних бібліотек.

У професійній підготовці майбутніх педагогів чільне місце відводилося організації їхньої самостійної навчальної діяльності тренувального характеру, що була спрямована на відпрацювання професійно важливих знань, умінь i навичок. Наприклад, під час вивчення англійської мови студентам пропонували виконувати різні вправи тренувального характеру, зокрема за допомогою застосування матеріалів таких сайтів, як: https://skyeng.ru/articles, https://www.english-online.at/index.htm, https://www.rong-chang.com/reading.htm тощо.

Майбутніх учителів також залучали до участі в електронних дидактичних іграх. Наприклад, під час вивчення педагогіки в групі завдань репродуктивного рівня їм пропонувалася гра «Стрільба по умовним мішеням», у різних видах якої вистрілами необхідно було позначити певні педагогічні терміни, явища чи дати подій.

У свою чергу організація самостійної навчальної діяльності продуктивного характеру відбувалася 3 використанням широкого спектру цифрових технологій (мультимедійних, телекомунікаційних, інтернеттехнологій, хмарних тощо). Так, традиційними для вищої школи видами самостійної діяльності здобувачів $€$ самостійна підготовка до лекційних, семінарських і практичних занять, зокрема написання повідомлень, доповідей, рефератів, підготовка відеопрезентацій i виконання інших завдань. Це 
спонукало студентів до здійснення пошуку й опрацювання потрібної їм інформації за допомогою відповідних цифрових інформаційних ресурсів.

Під час організації самостійної діяльності майбутніх учителів значна увага також приділялася залученню їх до розробки власних цифрових дидактичних матеріалів, які могли стати їм корисними в майбутній професійній діяльності. Наприклад, здобувачі розробляли електронні вікторини, тести, створювали цифрові ребуси та кросворди. Для створення цих завдань було використано безкоштовний універсальний цифровий конструктор Online Test Pad, за допомогою якого можна розробляти різного виду цифрові навчальні завдання: тести, кросворди, сканворди, логічні ігри тощо. Важливою перевагою зазначеної програми $є$ можливість створення дидактичних матеріалів українською мовою.

Наприклад, одна із здобувачів вищої педагогічної освіти розробила цифровий тест на тему «Дидактика», який було запропоновано для виконання іншим учасникам педагогічної взаємодії. Крім того, вона виступила 3 відповідною відеопрезентацією на тему «Створення тестів».

Для закріплення знань здобувачів 3 педагогіки та вдосконалення їхньої цифрової компетентності їм також пропонувалося створити авторські кросворди за допомогою цифрових конструкторів слів. У цьому плані в пригоді став конструктор Cross. За його допомогою для складання кросворда учасники мали тільки відібрати потрібні слова та правильно сформулювати завдання для заповнення цього кросворда, використовуючи відповідний глосарій. Розташування слів у такому кросворді визначалося самою програмою.

В організації самостійної навчальної діяльності студентів чільне місце відводилося виконанню ними завдань творчого характеру, зокрема розробленню цифрових проєктів, які передбачали самостійне, розгорнуте виконання учасниками конкретного завдання та досягнення значущого для них результату на основі використання певних цифрових технологій. Так, одна зі студенток створила цифровий проєкт «Використання народних прислів їв та приказок у виховній роботі з учнями». Цей проєкт створено в безкоштовному офісному пакеті Google Docs з використанням текстового редактора.

На четвертому (контрольно-оцінному) етапі організації самостійної навчальної діяльності майбутніх вчителів на основі використання цифрових технологій забезпечувалися самоконтроль і самооцінка засвоєних знань, умінь, компетенцій. Для цього було використано такі електронні засоби, як: електронне тестування, цифрові системи контролю знань студентів тощо. Особливе місце на вказаному етапі відводилося створенню здобувачами цифрового портфоліо навчальних досягнень, яке не тільки давало можливість оперативно відображати й оцінювати навчальні досягнення майбутнього вчителя, але й забезпечувало керування ним процесом власного особистіснопрофесійного розвитку.

Відзначимо, що загалом студенти самостійно визначали структуру та зміст своїх портфоліо, проте викладачі рекомендували включити до нього такі 
матеріали: скан-копії письмових контрольних i самостійних робіт, есе, презентації до текстів повідомлень і доповідей тощо; звіти та відгуки про проходження виробничої практики; сертифікати про участь у семінарах, форумах, конференціях, вивчення додаткових курсів; самостійно розроблені цифрові навчальні матеріали (тести, кросворди, творчі завдання тощо).

Для створення зазначеного портфоліо студенти могли використовувати різні сервіси мережі Інтернет, проте більшість із них віддали перевагу Google Sites (https://sites.google.com/new?pli=1). Створюючи портфоліо, майбутні педагоги спочатку давали назву головній сторінці сайту, а потім із меню «Панелі керування» до неї додавали інші сторінки з відповідними назвами. За допомогою вибору відповідних кнопок на «Панелі керування» студенти мали можливість додати до змісту портфоліо певні текстові матеріали, зображення предметів, файли з комп'ютера чи іншого носія інформації, тобто відобразити власні навчальні досягнення в різних формах.

Табличя

\section{Узагальнені результати експериментальної роботи}

\begin{tabular}{|l|c|c|c|}
\hline Критерії й показники ефективної організації & \multicolumn{2}{|c|}{ Приріст кількості студентів (у \%) } \\
\cline { 2 - 4 } $\begin{array}{l}\text { самостійної навчальної діяльності студентів засобами } \\
\text { цифрового освітнього середовища }\end{array}$ & $\begin{array}{c}\text { Високий } \\
\text { рівень }\end{array}$ & $\begin{array}{c}\text { Середній } \\
\text { рівень }\end{array}$ & $\begin{array}{c}\text { Низький } \\
\text { рівень }\end{array}$ \\
\hline $\begin{array}{l}\text { Мотиваційний (сформованість у студентів мотивів щодо } \\
\text { здійснення самостійної навчальної діяльності на основі } \\
\text { використання цифрових технологій) }\end{array}$ & $+18,1$ & $+21,3$ & $-39,4$ \\
\hline $\begin{array}{l}\text { Когнітивний (сформованість знань, необхідних для } \\
\text { здійснення самостійної навчальної діяльності на основі } \\
\text { застосування цифрових технологій) }\end{array}$ & $+11,9$ & $+17,4$ & $-29,3$ \\
\hline $\begin{array}{l}\text { Процесуальний (сформованість умінь, необхідних для } \\
\text { здійснення самостійної навчальної діяльності на основі } \\
\text { використання цифрових технологій) }\end{array}$ & $+9,4$ & $+15,4$ & $-24,8$ \\
\hline
\end{tabular}

Для оцінювання результатів організації самостійної навчальної діяльності майбутніх учителів використовувалися різні методи (електронне анкетування, тестування, експертне оцінювання, самооцінювання студентів тощо), що дало змогу зробити об'єктивний висновок про динаміку результатів самостійної навчальної діяльності майбутніх учителів, а як наслідок - про ефективність розробленої моделі. Основні узагальнені результати експериментальної роботи наведено в таблиці.

Обговорення. Результати наукових розвідок $є$ підставою для твердження, що питання організації самостійної навчальної діяльності майбутніх учителів на основі використання цифрових технологій знаходяться в центрі уваги багатьох науковців. Проте на сьогоднішній день відсутній алгоритм організації зазначеної діяльності та експериментальна перевірка його ефективності.

Висновки. В умовах активної інтеграції вітчизняної освіти в європейський простір, реформування системи загальної середньої освіти на засадах Нової української школи надзвичайно актуальною $є$ потреба в підвищенні якості 
підготовки майбутніх учителів у вищій школі. Одним із дієвих шляхів реалізації цього завдання $є$ підвищення ефективності організації самостійної навчальної діяльності студентів педагогічних спеціальностей на основі використання цифрових технологій.

Із цією метою було розроблено авторську модель організації самостійної навчальної діяльності майбутніх педагогів на основі використання цифрових технологій, що включає концептуально-цільовий, структурно-змістовий, технологічно-процесуальний та критеріально-результативний блоки. Ефективність організації зазначеної діяльності студентів визначалася за допомогою використання мотиваційного, когнітивного й процесуального критеріїв, на підставі чого було виокремлено високий, середній і низький рівні iï організації.

Позитивні результати проведеного експерименту засвідчили, що реалізація розробленої моделі дійсно забезпечує підвищення ефективності організації самостійної навчальної діяльності майбутніх учителів на основі застосування цифрових технологій. Достовірність приросту отриманих даних підтверджена методами математичної статистики. Тому розроблена модель організації самостійної навчальної діяльності здобувачів вищої педагогічної освіти на основі використання цифрових технологій може бути успішно використана в процесі організації вказаної діяльності студентів іншими викладачами.

Проведене дослідження не вичерпує всіх аспектів порушеної проблеми. Подальшого вивчення потребують питання здійснення спеціальної підготовки викладачів до організації самостійної навчальної діяльності в умовах цифрового освітнього середовища та організації цієї діяльності з урахуванням профілю підготовки майбутніх учителів.

\section{ЛІТЕРАТУРА:}

Boyer N. R., Usinger P. Tracking pathways to success: triangulating learning success factors. International Journal of Self-Directed Learning. 2015. No. 12. P. 22-48.

Hall J. D. Self-directed learning characteristics of first-generation, college students participating in a summer bridge program: Doctoral dissertation. University of South Florida, 2011. 155 p. Available: http://scholarcommons.usf.edu/etd/3140. Accessed on: Feb. 6, 2020.

Knowles M. S. Self-Directed Learning: A Guide for Learners and Teachers. N.Y.: Cambridge Books, 1975. 135p.

Long H. B. Understanding Self-Direction in Learning. Practice \& Theory in Self-Directed Learning. B. Long (Ed.). Schaumburg, IL: Motorola University Press, 2000. P. 11-24.

Merriam S. B., Caffarella R. S., Baumgartner L. M. Learning in Adulthood: Comprehensive Guide [3rd ed.]. San Francisco: Jossey-Bas, San Francisco, 2007. 533 p.

Бойко Н. I. Інформаційно-пошукові технології як засіб оптимізації самостійної роботи студентів. Наукові записки: зб. наук. пр., Нац. пед. ун-т імені М. П. Драгоманова. Вип. 72, 2008. С. 70-78. 
Гончаренко С. Український педагогічний словник. К. : Либідь, 1997. 373 с.

Зимняя И. А. Педагогическая психология: учеб. М. : Логос, 1999. 384 с.

Малихін О. В. Зміст і сутність самостійної навчальної діяльності студентів: історія і сучасність. Українська мова і література в школах Украӥни. 2014. № 11. С. 24-28.

Овчарук О. В. Сучасні підходи до розвитку цифрової компетентності людини та цифрового громадянства в європейських країнах. Інформачійні технології $i$ засоби навчання. 2020. T. 76. № 2. C. 1-13.

Овчарук О. В. Цифрова компетентність вчителя нової української школи: збір. тез доповідей учасників всеукр. наук.-практ. семінару (Київ, 28 лют. 2018 р.). К. : Ін-т інформаційних технологій і засобів навчання НАПН України, 2018. С. 59-53, 2018

Рибак С. Б., Баумвальд Н. Б., Писарик Р. М. Сутність і структура самостійної навчальної діяльності студентів. URL: http://oldconf.neasmo.org.ua/node/932. Дата звернення: лют. 4, 2020.

Ткачова Н. О., Кабанська О. С. Педагогічний супровід самостійної навчально-пізнавальної діяльності студентів вищої школи. Гуманізащія навчально-виховного процесу: зб. наук. пр. ДВНЗ «Донбаський державний педагогічний університет». Х. : ТОВ «Вид-во HTMT», 2018. № 4 (90). С. 178-197.

\section{REFERENCES:}

Bojko, N. I. (2008). Informacijno-poshukovi texnologiyi yak zasib optymizaciyi samostijnoyi roboty studentiv [Information and search technologies as a means of students' independent work facilitating]. Naukovi zapysky : zb. nauk. pr., Nacz. ped. un-t imeni M. P. Dragomanova. Vyp. 72. S. 70-78. (in Ukrainian)

Boyer, N. R. \& Usinger, P. (2015).Tracking pathways to success: triangulating learning success factors. International Journal of Self-Directed Learning, No. 12. P. 22-48.

Goncharenko, S. (1997). Ukrayinskyj pedagogichnyj slovnyk [Ukrainian Pedagogical Dictionary]. Kyiv : Lybid, 373 s. (in Ukrainian)

Hall, J. D. (2011) Self-directed learning characteristics of first-generation, college students participating in a summer bridge program: Doctoral dissertation, University of South Florida. 155 p. [Online]. Available: http://scholarcommons.usf.edu/etd/3140. Accessed on: Feb. 6, 2020.

Knowles, M. S. (1975). Self-Directed Learning: A Guide for Learners and Teachers. N.Y. : Cambridge Books. $135 \mathrm{p}$.

Long, H. B. (2000). Understanding Self-Direction in Learning. Practice \& Theory in SelfDirectedLearning. H. B. Long (Ed.). Schaumburg, IL: Motorola University Press. P. 11-24.

Malyxin, O. V. (2014). Zmist i sutnist samostijnoyi navchalnoyi diyalnosti studentiv : istoriya i suchasnist [The Content and Essence of Students' Educational Self-activity: The History and Modernity]. Ukrayinska mova i literatura $v$ shkolax Ukrayiny. № 11. S. 24-28. (in Ukrainian)

Merriam, S. B., Caffarella, R. S. \& Baumgartner, L. M. (2007). Learning in Adulthood: Comprehensive Guide [3rd ed.]. San Francisco: Jossey-Bas, San Francisco. 533 p.

Ovcharuk, O. V. (2018). Cyfrova kompetentnist vchytelya novoyi ukrayinskoyi shkoly [Digital Competence of the Teacher of the New Ukrainian School] : zbir. tez dopovidej uchasnykiv vseukr. nauk.-prakt. seminaru (Kyyiv, 28 lyut. 2018 r.). Kyyiv : In-t informacijny`x texnologij i zasobiv navchannya NAPN Ukrayiny, S. 59-53. (in Ukrainian)

Ovcharuk, O. V. (2020). Suchasni pidxody do rozvytku cyfrovoyi kompetentnosti lyudyny ta cyfrovogo gromadyanstva $\mathrm{v}$ yevropejskyx krayinax [Modern approaches to digital competency development of a person and digital citizenship in European countries]. Informacijni texnologiyi i zasoby navchannya. T. 76. № 2. S. 1-13. (in Ukrainian) 
Rybak, S. B., Baumvald, N. B. \& Pysaryk, R. M. (2020). Sutnist i struktura samostijnoyi navchalnoyi diyalnosti studentiv [The essence and structure of students'selfeducational activities of students]. Available: http://oldconf.neasmo.org.ua/node/932. Data zvernennya: lyut. 4. (in Ukrainian)

Tkachova, N. O. \& Kabanska, O. S. (2018). Pedagogichnyj suprovid samostijnoyi navchalnopiznavalnoyi diyalnosti studentiv vyshhoyi shkoly [The pedagogical support of independent educational and cognitive activities of students of higher education institutions]. Gumanizaciya navchalno-vyxovnogo procesu: zb. nauk. pr. DVNZ «Donbaskyj derzhavnyj pedagogichnyj universytet». Xarkiv : TOV «Vyd-vo NTMT», № 4 (90). S. 178-197. (in Ukrainian)

Zymnyaya, Y. A. (1999). Pedagogycheskaya psyxologyya [Education Psychology]: ucheb. Moskva : Logos, 384 s. (In Russian)

Інформація про авторів:
Ткачов Артем Сергійович:
ORCID: https://orcid.org/0000-0002-4488-
1466; доктор педагогічних наук, доцент
кафедри початкової і професійної освіти
Харківського національного педагогічного
університету імені Г. С. Сковороди; вул.
Валентинівська, 2, м. Харків, Україна,
61166
e-mail: tkachas2016@ ukr.net

Ткачова Наталія Олександрівна: ORCID: https://orcid.org/0000-0002-1892-9200; доктор педагогічних наук, професор, професор кафедри педагогіки Харківського національного педагогічного університету імені Г. С. Сковороди; вул. Валентинівська, 2, м. Харків, Україна, 61166 e-mail: tkachna2015@ukr.net

\section{Щебликіна Таміла Анатоліївна:}

ORCID: https://orcid.org/0000-0002-71353757; доктор педагогічних наук, доцент, завідувач кафедри англійської мови Харківського національного педагогічного університету імені Г.С. Сковороди; вул. Алчевських, 29, м. Харків, Україна, 61002 e-mail: tamila.shch@gmail.com

\section{Information about the authors:} Tkachov Artem Sergijovych:

ORCID: https://orcid.org/0000-0002-44881466; Doctor of Pedagogical Sciences,

Associate Professor of Primary and Professional Education Department of G.S. Skovoroda Kharkiv National Pedagogical University; Valentynivska Street, 2, Kharkiv, Ukraine, 61166 e-mail: tkachas2016@ukr.net

Tkachova Nataliia Oleksandrivna: ORCID: https://orcid.org/0000-0002-1892-9200; Doctor of Pedagogical Sciences, Professor, Professor of the Department of Pedagogy of G. S. Skovoroda Kharkiv National Pedagogical University; Valentynivska Street, 2, Kharkiv, Ukraine, 61166

e-mail: tkachna2015@ukr.net

\section{Tamila A. Shcheblykina}

ORCID: https://orcid.org/0000-0002-71353757; Doctor of Pedagogical Sciences, Associate Professor, Head of English Department of G. S. Skovoroda Kharkiv National Pedagogical University; Alchevskikh Street, 29, Kharkiv, Ukraine, 61002 e-mail: tamila.shch@gmail.com

Цитуйте цю статтю як: Ткачов А.С., Ткачова Н.О., Щебликіна Т.А. Авторська модель організації самостійної навчальної діяльності здобувачів вищої педагогічної освіти на основі використання цифрових технологій. Теорія та методика навчання та виховання. 2020. № 49. C. 113-127.

DOI: https://doi.org/10.34142/23128046.2020.49.10

Дата надходження статті до редакції: 10.11 .2020 р.

Стаття прийнята до друку: 25.11.2020 р. 